\title{
Point-of-Care Production of CAR-T Cells
}

\author{
Julio Delgado, Claire Roddie, and Michael Schmitt
}

CAR-T cells for clinical application are classified as advanced therapy medicinal products (ATMPs), and their manufacture is subject to laws and regulations governed by the European Medicines Agency (EMA) and by federal and regional authorities. CAR-T cells must be manufactured to achieve good manufacturing practice (GMP) compliance and are defined as potent products manufactured safely according to standardized methods under closely controlled, reproducible, and auditable conditions. BioPharma supplies the vast majority of CAR-T products for patients, but some academic centres have developed point-of-care cGMP CAR-T manufacturing capability, striving to uphold the same stringency of product quality while improving patient access to CAR-T cells and streamlining the costs of therapy. Point-of-care CAR-T manufacturing can only be performed in facilities with the appropriate regulatory approvals in place.

\footnotetext{
J. Delgado

Department of Haematology, Hospital Clinic of Barcelona, Barcelona, Spain

e-mail: JDELGADO@ clinic.cat

C. Roddie $(\bowtie)$

University College London Cancer Institute, London, UK

e-mail: c.roddie@ucl.ac.uk

\section{Schmitt}

Medizinische Klinik (Krehl-Klinik), Zentrum für Innere Medizin, Klinik für Hämatologie, Onkologie und Rheumatologie, Innere Medizin V, Heidelberg, Germany

e-mail: michael.schmitt@med.uni-heidelberg.de 


\section{GMP Vector Production}

Retroviral and lentiviral vectors are the most common gene delivery methods used in CAR-T manufacture. Viral vectors are considered an intermediate reagent by regulatory agencies, but in manufacturing, adherence to cGMP conditions is recommended.

Vector manufacture is conducted in grade A laminar flow cabinets in grade B clean rooms, commonly using HEK293T packaging cell lines derived from a master cell bank (MCB), assuming the appropriate licencing agreements with Rockfeller University are in place. Quality control of the MCB is outlined in Table 8.1 (Perpiñá et al. 2020).

Nonviral techniques for gene transduction or gene-editing are under investigation in preclinical and early clinical trials (Prommersberger et al. 2021).

The vector manufacturing process takes 10 to 14 days and is outlined here. Packaging cells are expanded in flasks and transferred into cell culture chambers followed by plasmid transfection using polyethylenimine. Fixed quantities of plasmids encoding CAR, viral envelope, and gagpol are required. Following transfection, supernatants containing the secreted vector are harvested, clarified using $0.45-\mathrm{mm}$ membranes, concentrated prior to diafiltration and cryopreservation in aliquots, and stored at $-80{ }^{\circ} \mathrm{C}$ until use. Quality measures are outlined in Table 8.2 (Castellà et al. 2019).

Table 8.1 Quality control for the HEK293T master cell bank

\begin{tabular}{l|l|l}
\hline Parameter & Method & Acceptance criteria \\
\hline Appearance & Visual inspection & $\begin{array}{l}\text { Presence of adherent cells with } \\
\text { thin extensions }\end{array}$ \\
\hline Sterility & Microbial growth & Sterile \\
\hline Mycoplasma & PCR & Absent \\
\hline Adventitious viruses & PCR & Absent \\
\hline Karyotype & G-band staining & Informative \\
\hline $\begin{array}{l}\text { Cell viability (\%) after } \\
\text { thawing }\end{array}$ & $\begin{array}{l}\text { Neubauer cell counting with } \\
\text { trypan blue exclusion }\end{array}$ & $>70 \%$ \\
\hline
\end{tabular}

Table 8.2 Quality control for GMP-grade virus production

\begin{tabular}{l|l|l}
\hline Parameter & Method & Acceptance criteria \\
\hline Appearance & Visual inspection & Yellowish liquid solution \\
\hline Viral titre & Limiting dilution & $>3.75 \times 10^{7} \mathrm{TU} / \mathrm{mL}$ \\
\hline Sterility & Microbial growth & Sterile \\
\hline Mycoplasma & PCR & Absent \\
\hline Identity & PCR & Positive \\
\hline Replication-competent lentivirus & Real-time PCR & Absent \\
\hline
\end{tabular}




\section{Manufacturing CAR-T Cells}

CAR-T cell manufacturing is conducted over approximately 8-12 days in an approved cGMP clean room facility in a closed or functionally closed system to reduce the risk of product contamination (Roddie et al. 2019; Schubert et al. 2019; Castellá et al. 2020).

Starting material for CAR-T cells includes CD3+ T cells derived from nonmobilized leukapheresis (see Chap. 6). Mandated leukapheresis requirements of academic manufacturers for total nucleated cells (TNCs) and CD3+ T cells must be defined; as an illustration, the Uni. Heidelberg HD-CAR-1 protocol (EudraCT No. 2016-004808-60) requires $20 \times 10^{8} \mathrm{TNCs}$ and $10 \times 10^{8} \mathrm{CD} 3+\mathrm{T}$ cells, similar to Novartis requirements for the manufacture of tisagenlecleucel. Leukapheresis material may be cryopreserved prior to manufacture, but in a bid to shorten the manufacturing process, there is a trend towards using fresh leukapheresis material. CAR-T manufacture is a stepwise process outlined in Table 8.3:

Upon completion of manufacturing, CAR-T products must comply with quality control/end-product specifications stipulated in the certificate of analysis. Parameters may vary, but CAR-T products are usually characterized for release according to

Table 8.3 CAR-T manufacturing methodology

\begin{tabular}{|c|c|c|}
\hline & Potential methods & Timepoint \\
\hline $\begin{array}{l}\text { Step 1: } \\
\text { T cell enrichment post- } \\
\text { leukapheresis (optional) }\end{array}$ & $\begin{array}{l}\text { Ficoll density gradient centrifugation; } \\
\text { elutriation; immunomagnetic bead separation }\end{array}$ & Day 1 \\
\hline $\begin{array}{l}\text { Step 2: } \\
\text { T cell activation using } \\
\text { synthetic antigen presenting } \\
\text { technologies (CD3 +/- } \\
\text { CD28) (required) }\end{array}$ & $\begin{array}{l}\text { Soluble monoclonal antibodies; Para-magnetic } \\
\text { anti-CD3/CD28 antibody coated beads; } \\
\text { polymeric biodegradable CD3/28 incorporating } \\
\text { nanomatrix (TransAct }{ }^{\mathrm{TM}} \text { ) }\end{array}$ & Days 1,2 \\
\hline $\begin{array}{l}\text { Step 3: } \\
\text { T cell stimulation (required) }\end{array}$ & $\begin{array}{l}\text { IL-2, IL-7, and IL-15 in the culture medium (as } \\
\text { per protocol) (Hoffmann et al. 2018; Gong } \\
\text { et al. 2019) }\end{array}$ & $\begin{array}{l}\text { From day } 1 \\
\text { onwards }\end{array}$ \\
\hline $\begin{array}{l}\text { Step 4: } \\
\text { Gene delivery/transduction } \\
\text { with a retroviral or lentiviral } \\
\text { CAR vector (required) }\end{array}$ & $\begin{array}{l}\text { In some processes, retronectin or Vectofusin }{ }^{\circledR} \text { is } \\
\text { used to enhance transduction (optional) }\end{array}$ & Days 2, 3 \\
\hline $\begin{array}{l}\text { Step 5: } \\
\text { T cell expansion (required) }\end{array}$ & $\begin{array}{l}\text { T-flasks, plates or culture bags; bioreactors, } \\
\text { e.g., G-Rex }{ }^{\mathrm{TM}} \text { flask (Wilson Wolf } \\
\text { Manufacturing); Xuri WAVETM Bioreactor } \\
\text { (GE Life Systems); CliniMACS Prodigy } \\
\text { (Miltenyi BioTec) }\end{array}$ & $\begin{array}{l}\text { Days } 3,4 \\
\text { and onwards }\end{array}$ \\
\hline $\begin{array}{l}\text { Step 6: } \\
\text { T cell harvest and } \\
\text { cryopreservation (required) }\end{array}$ & $\begin{array}{l}\text { The cryopreservation methodology often } \\
\text { mirrors processes defined for haematopoietic } \\
\text { cells. Methods include passive freezing } \\
\left(-80^{\circ} \mathrm{C} \text { freezer }\right) \text { and controlled-rate freezing }\end{array}$ & $\begin{array}{l}\text { Day } 8 \\
\text { onwards }\end{array}$ \\
\hline $\begin{array}{l}\text { Step 7: } \\
\text { CAR-T cell quality assurance } \\
\text { control and release testing }\end{array}$ & $\begin{array}{l}\text { In-process and end of process controls are } \\
\text { taken to ensure the product complies with } \\
\text { release criteria specifications }\end{array}$ & $\begin{array}{l}\text { Day } 8 \\
\text { onwards }\end{array}$ \\
\hline
\end{tabular}


Table 8.4 Quality control of CAR-T cell biology and microbiology

\begin{tabular}{|c|c|c|}
\hline Parameter & Method & Acceptance criteria \\
\hline Appearance & Visual inspection & Cloudy liquid solution \\
\hline CAR + cells $(\%)^{\mathrm{a}}$ & Flow cytometry & $>20 \%$ \\
\hline $\mathrm{CD} 3+$ cells $(\%)$ & Flow cytometry & $>70 \%$ \\
\hline Cell viability (\%) & $\begin{array}{l}\text { Neubauer cell counting with } \\
\text { trypan blue exclusion }\end{array}$ & $>70 \%$ \\
\hline Sterility & Microbial growth E. Ph. 2.6.1 & Sterile from bacteria/fungi \\
\hline Mycoplasma & $\mathrm{PCR}^{\mathrm{c}}$ & Absent \\
\hline Endotoxin & Chromogenic assay & $<0.5 \mathrm{EU} / \mathrm{mL}$ \\
\hline \multicolumn{3}{|l|}{ Optional/R\&D } \\
\hline $\begin{array}{l}\text { CAR/CD45RA/CCR7 } \\
\text { For detection of TE/ } \\
\text { TEM/TEMRA/TCM/TN } \\
\text { subpopulations }\end{array}$ & Flow cytometry & $\begin{array}{l}\text { A high proportion of immature } \mathrm{T} \\
\text { cells is desirable for a long- } \\
\text { lasting CAR-T cell effect in the } \\
\text { patient }\end{array}$ \\
\hline Cytotoxic potency & $\begin{array}{l}\text { Cr-51 release assays in tumour } \\
\text { CAR-T cell co-culture, } \\
\text { assessed by flow cytometry }\end{array}$ & $\begin{array}{l}>40 \% \text { killing at an effector/target } \\
\text { ratio of 10:1 (or higher ratio) in a } \\
\text { 4-h assay }\end{array}$ \\
\hline Adventitious viruses & PCR & Absent \\
\hline $\begin{array}{l}\text { Number of transgene } \\
\text { copies/cell }\end{array}$ & $\begin{array}{l}\text { Real-time PCR (Kunz et al. } \\
\text { 2019; Schubert et al. 2020) }\end{array}$ & $<10$ (range $<7-15$ !) copies/cell ${ }^{\mathrm{d}}$ \\
\hline
\end{tabular}

${ }^{\mathrm{a}}$ Automated cell counters, such as Luna ${ }^{\mathrm{TM}}$, are highly recommended

${ }^{\mathrm{b}}$ Highly specific detection reagents (e.g., the Miltenyi Detection Reagent ${ }^{\mathrm{TM}}$ ) are strongly advised to distinguish CAR-T cells from the negative fraction

${ }^{c}$ European standards stipulate PCR methodology, in contrast to US regulations, which require serology

${ }^{\mathrm{d}}$ Differs between countries and products

immunophenotypic, functional, and sterility assessments (Table 8.4). An out-ofspecification (OOS) product cannot be released in the usual way, and its clinical use is at the discretion of the treating physician in concert with the regulatory authorities, informed through an OOS report.

\section{Summary and Key Points}

- Point-of-care/decentralized CAR-T cell manufacturing has the potential to enhance patient access to CAR-T products.

- Limitations include the requirement for local cGMP facilities/trained staff and lack of standardization across multiple sites.

- Potential solutions include implementation of standardized, semiautomated manufacturing platforms, such as the Miltenyi CliniMACS Prodigy ${ }^{\mathrm{TM}}$, and the use of standardized release assays reported in a common format across manufacturing sites to enable the manufacture of consistent, high-quality products between patients. 


\section{References}

Castellà M, et al. Development of a novel anti-CD19 chimeric antigen receptor: a paradigm for an affordable CAR-T cell production at academic institutions. Mol Ther Methods Clin Dev. 2019;12:134-44.

Castellá M, et al. Point-of-care CAR-T cell production (ARI-0001) using a closed semi-automatic bioreactor: experience from an academic phase I clinical trial. Front Immunol. 2020;11:482.

Gong W, Hoffmann JM, Stock S, Wang L, Liu Y, Schubert ML, Neuber B, Hückelhoven-Krauss A, Gern U, Schmitt A, Müller-Tidow C, Shiku H, Schmitt M, Sellner L. Comparison of IL-2 vs IL-7/IL-15 for the generation of NY-ESO-1-specific T cells. Cancer Immunol Immunother. 2019;68(7):1195-209. Epub 2019 Jun 8. https://doi.org/10.1007/s00262-019-02354-4.

Hoffmann J-M, Schubert M-L, Wang L, Hückelhoven A, Sellner L, Stock S, Schmitt A, Kleist C, Gern A, Loskog A, Wuchter A, Hofmann S, Ho AD, Müller-Tidow C, Dreger P, Schmitt M. Differences in expansion potential of naive chimeric antigen receptor T cells from healthy donors and untreated chronic lymphocytic leukemia patients. Front Immunol. 2018;8:1956. https://doi.org/10.3389/fimmu.2017.01956.

Kunz A, Gern U, Schmitt A, Neuber N, Wang L, Hückelhoven-Krauss A, Michels B, Hofmann S, Müller-Tidow C, Dreger P, Schmitt M, Schubert M-L. Optimized assessment of qPCR-based vector copy numbers as a safety parameter for GMP-grade CAR-T cells and monitoring of frequency in patients. Mol Ther Methods Clin Dev. 2019;17:448-54.

Perpiñá U, et al. Cell banking of HEK293T cell line for clinical-grade lentiviral particles manufacturing. Transl Med Comm. 2020;5:22.

Prommersberger S, Reiser M, Beckmann J, Danhof S, Amberger M, Quade-Lyssy P, et al. CARAMBA: a first-in-human clinical trial with SLAMF7 CAR-T cells prepared by virusfree Sleeping Beauty gene transfer to treat multiple myeloma. Gene Ther. 2021;28(9):560-71. https://doi.org/10.1038/s41434-021-00254-w. Epub 2021 Apr 13. PMID: 33846552.

Roddie $\mathrm{C}$, et al. Manufacturing chimeric antigen receptor $\mathrm{T}$ cells: issues and challenges. Cytotherapy. 2019;21(3):327-40. https://doi.org/10.1016/j.jcyt.2018.11.009.

Schubert M-L, Schmitt A, Sellner L, Neuber B, Kunz J, Wuchter P, Kunz A, Gern U, Michels B, Hofmann S, Hückelhoven-Krauss A, Kulozik A, Ho AD, Müller-Tidow C, Dreger P, Schmitt M. Treatment of patients with relapsed or refractory CD19+ lymphoid disease with T lymphocytes transduced by RV-SFG. CD19.CD28.4-1BBzeta retroviral vector: a unicentre phase I/II clinical trial protocol. BMJ Open. 2019;9:e026644. https://doi.org/10.1136/ bmjopen-2018-026644.

Schubert ML, Kunz A, Schmitt A, Neuber B, Wang L, Hückelhoven-Krauss A, Langner S, Michels B, Wick A, Daniel V, Müller-Tidow C, Dreger P, Schmitt M. Assessment of CAR-T cell frequencies in Axicabtagene Ciloleucel and Tisagenlecleucel patients using duplex quantitative PCR. Cancers (Basel). 2020;12(10):2820.

Open Access This chapter is licensed under the terms of the Creative Commons Attribution 4.0 International License (http://creativecommons.org/licenses/by/4.0/), which permits use, sharing, adaptation, distribution and reproduction in any medium or format, as long as you give appropriate credit to the original author(s) and the source, provide a link to the Creative Commons license and indicate if changes were made.

The images or other third party material in this chapter are included in the chapter's Creative Commons license, unless indicated otherwise in a credit line to the material. If material is not included in the chapter's Creative Commons license and your intended use is not permitted by statutory regulation or exceeds the permitted use, you will need to obtain permission directly from the copyright holder.

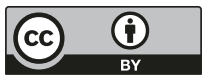

